Article

\title{
Local Environmental Conditions Promote High Turnover Diversity of Benthic Deep-Sea Fungi in the Ross Sea (Antarctica)
}

\author{
Giulio Barone ${ }^{1,2} \mathbb{D}$, Cinzia Corinaldesi ${ }^{3}$, Eugenio Rastelli ${ }^{4}\left(\mathbb{D}\right.$, Michael Tangherlini $^{5}\left(\mathbb{D}\right.$, Stefano Varrella ${ }^{3}$ (D), \\ Roberto Danovaro ${ }^{2,6}$ (D) and Antonio Dell'Anno ${ }^{2, *(\mathbb{D})}$
}

check for

updates

Citation: Barone, G.; Corinaldesi, C.; Rastelli, E.; Tangherlini, M.; Varrella, S.; Danovaro, R.; Dell'Anno, A. Local Environmental Conditions Promote High Turnover Diversity of Benthic Deep-Sea Fungi in the Ross Sea (Antarctica). J. Fungi 2022, 8, 65. https://doi.org/10.3390/jof8010065

Academic Editor: Federico Baltar

Received: 20 December 2021

Accepted: 5 January 2022

Published: 8 January 2022

Publisher's Note: MDPI stays neutral with regard to jurisdictional claims in published maps and institutional affiliations.

Copyright: (C) 2022 by the authors. Licensee MDPI, Basel, Switzerland. This article is an open access article distributed under the terms and conditions of the Creative Commons Attribution (CC BY) license (https:// creativecommons.org/licenses/by/ $4.0 /)$.
1 Institute for Marine Biological Resources and Biotechnology, National Research Council, Largo Fiera della Pesca 2, 60125 Ancona, Italy; giulio.barone@irbim.cnr.it

2 Department of Life and Environmental Sciences, Polytechnic University of Marche, Via Brecce Bianche, 60131 Ancona, Italy; r.danovaro@univpm.it

3 Department of Materials, Environmental Sciences and Urban Planning, Polytechnic University of Marche, Via Brecce Bianche, 60131 Ancona, Italy; c.corinaldesi@staff.univpm.it (C.C.); s.varrella@univpm.it (S.V.)

4 Department of Marine Biotechnology, Stazione Zoologica Anton Dohrn, Fano Marine Centre, Viale Adriatico 1-N, 61032 Fano, Italy; eugenio.rastelli@szn.it

5 Department of Research Infrastructures for Marine Biological Resources, Stazione Zoologica Anton Dohrn, Fano Marine Centre, Viale Adriatico 1-N, 61032 Fano, Italy; michael.tangherlini@szn.it

6 Stazione Zoologica Anton Dohrn, Villa Comunale, 80121 Naples, Italy

* Correspondence: a.dellanno@univpm.it

\begin{abstract}
Fungi are a ubiquitous component of marine systems, but their quantitative relevance, biodiversity and ecological role in benthic deep-sea ecosystems remain largely unexplored. In this study, we investigated fungal abundance, diversity and assemblage composition in two benthic deep-sea sites of the Ross Sea (Southern Ocean, Antarctica), characterized by different environmental conditions (i.e., temperature, salinity, trophic availability). Our results indicate that fungal abundance (estimated as the number of $18 \mathrm{~S}$ rDNA copies $\mathrm{g}^{-1}$ ) varied by almost one order of magnitude between the two benthic sites, consistently with changes in sediment characteristics and trophic availability. The highest fungal richness (in terms of Amplicon Sequence Variants-ASVs) was encountered in the sediments characterized by the highest organic matter content, indicating potential control of trophic availability on fungal diversity. The composition of fungal assemblages was highly diverse between sites and within each site (similarity less than 10\%), suggesting that differences in environmental and ecological characteristics occurring even at a small spatial scale can promote high turnover diversity. Overall, this study provides new insights on the factors influencing the abundance and diversity of benthic deep-sea fungi inhabiting the Ross Sea, and also paves the way for a better understanding of the potential responses of benthic deep-sea fungi inhabiting Antarctic ecosystems in light of current and future climate changes.
\end{abstract}

Keywords: deep-sea sediments; fungal diversity; trophic conditions; Antarctica; Ross Sea

\section{Introduction}

The Southern Ocean, surrounding Antarctica, plays a key role in global ocean circulation and biogeochemical cycles [1,2]. Here, primary productivity and carbon export to the seafloor are highly variable in space and time, with the highest rates of primary production occurring during the austral summer in the coastal polynyas (regions of open water surrounded by sea ice; [3,4]), marginal ice zone [5] and continental shelf [6-8]. Despite the extreme environmental conditions (e.g., low temperature, highly variable nutrient availability), the Southern Ocean hosts rich and diverse benthic deep-sea assemblages, including several endemic species $[9,10]$. 
Microbial assemblages in benthic deep-sea ecosystems play an important role in C and nutrient cycling and transfer of energy and material to the higher trophic levels [11]. Besides prokaryotes, fungi are widespread in deep-sea environments spanning from hypersaline anoxic basins [12-14] to cold seeps [15,16], from hydrothermal vents [17-19] to surface and subsurface sediments [13,20-24], including benthic Antarctic systems [25-28] and references therein). Theoretical estimates suggest that fungi can be the most diversified component of eukaryotes on Earth, with more than 5 million species of which only 5\% have been described $[29,30]$. This gap applies in particular to deep-sea ecosystems, where a significant fraction of fungal diversity is still unknown [24,31,32]. Recent studies suggest that a variety of environmental factors (e.g., temperature, salinity, nutrient availability) can influence the diversity and assemblage composition of fungi in marine ecosystems [33,34]. However, factors controlling the distribution and diversity of fungi in benthic deep-sea ecosystems remain largely unexplored to date [24] and even less is known of fungi inhabiting the Southern Ocean. In deep-sea ecosystems, fungi are not only highly diversified, but they are likely involved in the degradation and cycling of organic matter [13,18,35-38]. In benthic deep-sea ecosystems, organic matter mainly consists of refractory organic compounds [39,40], and fungi are known to be efficient degraders of complex organic molecules not suitable for other heterotrophic microbes [41,42]. However, their role in $\mathrm{C}$ and nutrient cycling in benthic deep-sea ecosystems remains poorly understood [24].

Global climate change is altering marine biodiversity and food web dynamics, and such effects are particularly pronounced at high latitudes [43-45]. Changes in environmental conditions (e.g., temperature, salinity, nutrient availability) due to climate changes in polar regions can induce a domino effect that could impact biodiversity and ecosystem functioning from the continental shelf down to the deep seafloor [46,47]. Nevertheless, information on benthic deep-sea fungal assemblages of Antarctic ecosystems is scant and insufficient to understand and predict how these components will respond to the expected changes in environmental conditions.

In this study, we investigated the abundance, diversity and assemblage composition of fungi in two benthic deep-sea sites of the Ross Sea (one of the most productive sectors of the whole Southern Ocean; [48]), characterized by different environmental conditions in terms of trophic availability and thermohaline regime. This work aims at shedding light on the ecology of benthic deep-sea fungi and factors shaping their distribution at different spatial scales (i.e., between stations of the same site and between sites). This information is crucial for better comprehension of the responses of benthic fungal assemblages inhabiting Antarctic ecosystems, and also in light of climate change scenarios.

\section{Materials and Methods}

\subsection{Study Area and Sampling Strategy}

Sediment samples were collected in the Ross Sea, Southern Ocean (Figure 1), during the austral summer 2017 onboard the research vessel $M / N$ Italica in the framework of the XXXII Italian Antarctic Expedition. Samples were collected at two different sites, named B and C, located about $170 \mathrm{~km}$ from each other. Site B (average depth of ca. $580 \mathrm{~m}$ ) is located in the cross-shelf valley in the northern part of the Joides basin, and it is characterized by bio-siliceous olive-gray mud sediments. Site $C$ is located at ca. $430 \mathrm{~m}$ depth close to the shelf break on the northern flank of the Mawson Bank, and it is characterized by sand, gravel, pebbles and coarse biogenic carbonate debris and high near-bottom current velocities (up to $20 \mathrm{~cm} \mathrm{~s}^{-1}$; [49]). At both sites, two stations located at ca. $2 \mathrm{~km}$ from each other were selected to investigate spatial variability within the same site (hereafter defined B1 and B2 and C1 and C2). At each station, the main physical-chemical characteristics of the bottom waters were acquired by CTD casts along with the collection of undisturbed sediment samples by three independent box corer deployments. Once on board, sediment subsamples of the top $1 \mathrm{~cm}$ were collected and stored at $-20{ }^{\circ} \mathrm{C}$ until laboratory analyses for the determination of organic matter quantity and quality (used as a proxy of trophic 
conditions [50,51]), fungal abundance, diversity and assemblage composition. All samples were processed within six months of their collection.

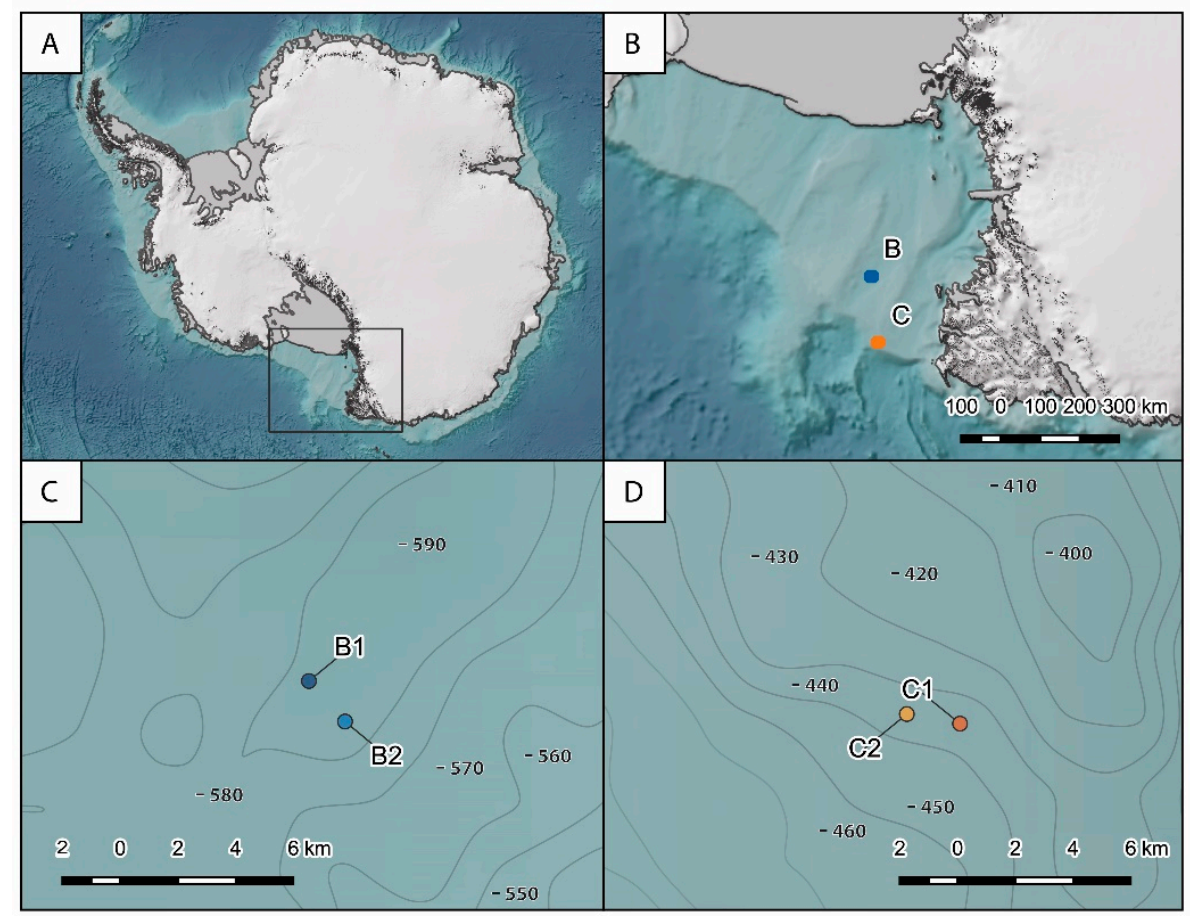

Figure 1. Location of the study area (A) and sampling locations of the two benthic deep-sea sites investigated (B) and of the stations within sites B (C) and C (D). The map was generated upon freely available layers within QGIS 3.22 environment (http:/ / www.qgis.org; accessed on 7 January 2022).

\subsection{Trophic Conditions}

Trophic conditions of benthic systems were assessed on the basis of the quantity and biochemical composition of organic matter [50,51]. Chloroplastic pigments (chlorophyll-a and phaeopigments) were analyzed fluorometrically [52]. Pigments were extracted with $90 \%$ acetone $\left(12 \mathrm{~h}\right.$ in the dark at $\left.4{ }^{\circ} \mathrm{C}\right)$. After centrifugation, the supernatant was used to determine the functional chlorophyll-a and then acidified with $0.1 \mathrm{~N} \mathrm{HCl}$ to estimate phaeopigments. Total phytopigment concentration (CPE) was defined as the sum of chlorophyll-a and phaeopigment concentrations.

Protein, carbohydrate and lipid concentrations in the sediment were determined according to previously described protocols [52]. Briefly, protein concentration was assessed by a colorimetric method, based on the reaction of proteins with copper tartrate and the Folin-Ciocalteau in a basic environment ( $\mathrm{pH} 10)$, which provides a stable blue coloration with an intensity proportional to protein concentration. Carbohydrate concentration was determined spectrophotometrically based on the reaction between carbohydrates and phenol in the presence of sulfuric acid, which provides a coloration whose intensity is proportional to carbohydrate concentration. Lipids were extracted by direct elution with chloroform and methanol followed by reaction with sulfuric acid and determination by a colorimetric method. Protein, carbohydrate and lipid concentrations were expressed as albumin, glucose and tripalmitin equivalents, respectively. All analyses were carried out in three replicates. Protein, carbohydrate and lipid concentrations were converted to carbon equivalents (conversion factors: $0.49,0.40$ and $0.75 \mathrm{gC} \mathrm{g}^{-1}$, respectively) to determine biopolymeric $\mathrm{C}$ content (BPC) in the sediments [50]. The protein to carbohydrate ratio (P:C) was used as a proxy of organic matter quality [51]. 


\subsection{DNA Extraction and Purification for Molecular Analysis}

DNA was extracted and purified from sediment samples using PowerSoil DNA isolation kit (QIAGEN), following the manufacturer's instruction with slight modifications to remove extracellular DNA (based on three subsequent washing steps), before DNA extraction [52].

\subsection{Fungal Abundance Estimated by Quantitative Real-Time PCR (qPCR)}

To estimate fungal abundance, DNA aliquots were used for quantitative real-time PCR (qPCR) analysis of the fungal-specific 18S rRNA gene [53]. Briefly, fungi-specific primers (FR1 5' -AIC CAT TCA ATC GGT AIT-3') and FF390 (5'-CGA TAA CGA ACG AGA CCT-3'), which amplify a $18 \mathrm{~S}$ rRNA gene fragment of about $350 \mathrm{bp}$ [54], were used with the Sensi-FAST SYBR Q-PCR kit (Bioline, London, UK). The $15 \mu \mathrm{L}$ reactions contained $8 \mu \mathrm{l}$ Sensi-FAST master mix, $1 \mu \mathrm{L}$ of each primer (final concentration $1 \mu \mathrm{M}$ ), $1 \mu \mathrm{L}$ of DNA template and $5 \mu \mathrm{L}$ nuclease-free molecular-grade water [53]. A Bio-Rad iQ5 instrument was used to perform qPCR analyses using the following thermal protocol: $94^{\circ} \mathrm{C}$ for $3 \mathrm{~min}$., then 40 cycles of $94{ }^{\circ} \mathrm{C}$ for $10 \mathrm{~s}$, annealing at $50{ }^{\circ} \mathrm{C}$ for $15 \mathrm{~s}$, elongation at $72{ }^{\circ} \mathrm{C}$ for $20 \mathrm{~s}$ and acquisition of fluorescence data at $82{ }^{\circ} \mathrm{C}$. The CFX Manager ${ }^{\mathrm{TM}}$ (v3.1) software was used to calculate $\mathrm{Cq}$, efficiency (E) and $\mathrm{R}^{2}$ values of standard curves for each plate and to quantify $18 \mathrm{~S}$ rDNA copy numbers present in the samples analyzed. Standard curves were generated using known concentrations of Aspergillus niger 18S rDNA. The number of fungal $18 \mathrm{~S}$ rDNA copies was standardized per gram of dry sediment.

\subsection{Fungal Diversity and Assemblage Composition}

DNA extracted from two sediment samples collected at each station by independent box corer deployments was amplified using the primer set ITS1F (5'-GGAAGTAAAAGTCGTAACAAGG-3') and ITS2 (5'- GCTGCGTTCTTCATCGATGC-3'), which amplify the internal transcribed spacer-1 (ITS1) region of the fungal rRNA gene [55,56]. Amplicons were sequenced on an Illumina MiSeq platform by the LGC group (Berlin, Germany), following the Earth Microbiome Project protocols (http:/ / www.earthmicrobiome.org/emp-standard-protocols/; accessed on 15 September 2018). Paired-end sequences were analyzed within the QIIME2 environment [57]. First, the ITSxpress plugin was used to trim sequences targeting the ITS1 region [58]; then, trimmed paired-end sequences were analyzed through the DADA2 procedure [59], and the resulting biologically significant Amplicon Sequence Variants (ASVs) were compared against the UNITE database (Version: 8.3; Last updated: 11 December 2020) for taxonomic affiliation [58]. Taxonomic affiliation was performed through the USEARCH SINTAX procedure [60] using three different thresholds: 0.8 (default), 0.6 and 0.5 to evaluate potential distant affiliations. To allow for a proper comparison among samples, the ASV table was then rarefied to 900 randomly selected sequences, corresponding to the lowest read count obtained in our samples [61,62].

\subsection{Data Analyses}

Differences in environmental and trophic variables, fungal abundance (as 18S rDNA copy number) and ASV richness between and within sites were tested by permutational two-way nested analysis of variance (2-way nested PERMANOVA; [63,64], considering the two factors Site (2 levels: B and C) and Station (nested in Site, 2 levels: 1 and 2). P-values were calculated with unrestricted permutation of raw data (perm.: 9999) with adonis function in vegan package. To investigate the relationships between fungal abundance and ASV richness and environmental and trophic variables, Spearman Rank correlation analyses were carried out.

The rarefied ASV table was used to assess the number of either "core" ASVs (i.e., at least one ASV present in all samples) and "exclusive" ASVs (i.e., ASVs found only in a single sample) and the output was visualized by network analysis through the Gephi package [65]. To determine similarities of the fungal assemblage composition between stations and sites, a similarity percentage analysis (SIMPER; [66]) was carried out. To identify potential factors influencing fungal assemblage composition, DistLM routine and distance-based 
redundancy analyses (dbRDA) were carried out with Primer+PERMANOVA (v7) [67]. In particular, temperature, salinity and dissolved oxygen concentrations of the bottom waters and quantity (i.e., biopolymeric $C$ concentrations and total phytopigment content) and quality (protein to carbohydrate ratio) of organic matter in the sediments were used as predictor variables.

\section{Results and Discussion}

The thermohaline conditions of bottom waters of the benthic systems investigated in the present study changed widely, with temperature values ranging from $-1.880{ }^{\circ} \mathrm{C}$ to $-0.046{ }^{\circ} \mathrm{C}$ and salinity values ranging from 34.650 to 34.756 (Table 1). Stations at Site $B$ were characterized by colder, saltier and more oxygenated waters than stations at Site $C$, reflecting differences in water mass characteristics. In particular, cold waters with temperatures below the surface freezing point observed at stations of Site B were associated with the Ice Shelf Water (ISW) overflowing on the continental slope of the Ross Sea [68]. The two benthic sites were also characterized by differences in terms of sediment grain size, which was mainly represented by silt-clay particles at stations of Site B and by coarse particles, including carbonate debris, at stations of Site C.

Table 1. Values of temperature, salinity and dissolved oxygen concentrations of the bottom waters and biopolymeric carbon and total phytopigment concentrations and protein to carbohydrate ratios $(\mathrm{P}: \mathrm{C})$ in the surface sediments of the different stations investigated. Mean values and standard deviations $( \pm)$ are reported.

\begin{tabular}{|c|c|c|c|c|c|c|c|}
\hline Site & Station & $\begin{array}{l}\text { Depth } \\
\text { (m) }\end{array}$ & $\begin{array}{c}\text { Latitude } \\
\text { EPSG: } 4326\end{array}$ & $\begin{array}{l}\text { Longitude } \\
\text { EPSG: } 4326\end{array}$ & $\begin{array}{c}\text { Temperature } \\
\left({ }^{\circ} \mathrm{C}\right)\end{array}$ & Salinity & $\begin{array}{c}\text { Dissolved Oxygen } \\
\left(\mathrm{mg} \mathrm{L}^{-1}\right)\end{array}$ \\
\hline B & B1 & 585 & -74.03951 & 175.07945 & $-1.88 \pm 0.0002$ & $34.752 \pm 0.0002$ & $10.96 \pm 0.05$ \\
\hline B & B2 & 587 & -74.01603 & 175.04279 & $-1.878 \pm 0.0002$ & $34.756 \pm 0.0001$ & $11 \pm 0.05$ \\
\hline $\mathrm{C}$ & $\mathrm{C} 1$ & 433 & -72.49527 & 174.94336 & $-0.5 \pm 0.001$ & $34.65 \pm 0.0002$ & $6.25 \pm 0.003$ \\
\hline $\mathrm{C}$ & $\mathrm{C} 2$ & 434 & -72.49967 & 174.99696 & $-0.046 \pm 0.0024$ & $34.667 \pm 0.0001$ & $9.92 \pm 0.005$ \\
\hline & & \multicolumn{2}{|c|}{$\begin{array}{c}\text { Biopolymeric Carbon } \\
\left(\mathrm{mg} \mathrm{g}^{-1}\right)\end{array}$} & \multicolumn{2}{|c|}{$\begin{array}{l}\text { Total phytopigments } \\
\qquad\left(\mu \mathrm{g} \mathrm{g}^{-1}\right)\end{array}$} & \multicolumn{2}{|c|}{$\mathrm{P}: \mathrm{C}$} \\
\hline B & B1 & \multicolumn{2}{|c|}{$3.23 \pm 0.23$} & \multicolumn{2}{|c|}{$3.28 \pm 1.27$} & \multicolumn{2}{|c|}{$0.39 \pm 0.1$} \\
\hline B & B2 & \multicolumn{2}{|c|}{$2.32 \pm 0.61$} & \multicolumn{2}{|c|}{$3.44 \pm 0.84$} & \multicolumn{2}{|c|}{$0.19 \pm 0.1$} \\
\hline $\mathrm{C}$ & $\mathrm{C} 1$ & \multicolumn{2}{|c|}{$0.28 \pm 0.08$} & \multicolumn{2}{|c|}{$0.33 \pm 0.08$} & \multicolumn{2}{|c|}{$0.7 \pm 0.19$} \\
\hline $\mathrm{C}$ & $\mathrm{C} 2$ & \multicolumn{2}{|c|}{$0.23 \pm 0.08$} & \multicolumn{2}{|c|}{$0.24 \pm 0.11$} & \multicolumn{2}{|c|}{$0.46 \pm 0.06$} \\
\hline
\end{tabular}

There is evidence that the distribution and accumulation of organic matter in surface sediments of deep-sea systems of the Ross Sea are influenced not only by vertical inputs from the upper water column, but also by lateral advection processes [69,70]. The formation and cascading of the Ice Shelf Water can represent an important process of $C$ supply to the sea bottom, which may be responsible for the high organic matter content observed at the benthic deep-sea stations of Site B (Table 1). Values of total phytopigment concentrations, a proxy of the organic material produced by photosynthesis in surface waters and settling on the seafloor, and biopolymeric $C$ concentrations in surface sediments of stations of Site B were, indeed, 10 times higher than those of Site $C$ stations (Table 1).

There is a general consensus that trophic availability controls the abundance and distribution of benthic deep-sea standing stocks from prokaryotes to meio- and macrofauna [71,72], but information on its relevance in influencing the distribution of deep-sea fungi is still largely lacking [24]. In this study, fungal abundance, expressed as fungal $18 \mathrm{~S}$ rDNA copies per gram of dry sediment, ranged from $1.3 \pm 0.7 \times 10^{6}$ copies g $^{-1}$ to $1.6 \pm 0.5 \times 10^{7}$ copies $^{-1}$ (Figure 2A,B). Our results fall within previously reported ranges for deep-sea sediments of the Pacific Ocean (from $3.5 \times 10^{6}$ to $5.2 \times 10^{7} 28 \mathrm{~S}$ rDNA copies $\mathrm{g}^{-1}$ [73]) and the Mediterranean Sea (from $1.4 \times 10^{6}$ to $5.1 \times 10^{7} 18 \mathrm{~S}$ rDNA copies $g^{-1}[24]$ ) and provide the first evidence of the quantitative importance of fungi in benthic deep-sea ecosystems of the Southern Ocean. Fungal abundance changed between 
and within sites (Site: Pseudo- $\mathrm{F}_{2,8}=5.27, p<0.05$; Station (Site): $\mathrm{F}_{1,8}=15.86, p<0.05$; Figure $2 \mathrm{~A}, \mathrm{~B})$, with values up to 1 order of magnitude higher at stations of Site $\mathrm{B}$ than at stations of Site C. Significant positive relationships were found between fungal abundance and total phytopigment and biopolymeric $\mathrm{C}$ concentrations in the sediment (Figure 3A,B). In particular, biopolymeric $C$ concentrations alone explained $87 \%$ of the total variation in fungal abundance $(t=8.1, p<0.001$, Spearman's $\rho=0.87)$. Overall, these findings suggest that benthic deep-sea fungi, besides prokaryotes, can be actively involved in the decomposition and utilization of organic matter settling on the seafloor, thus contributing to its cycling.
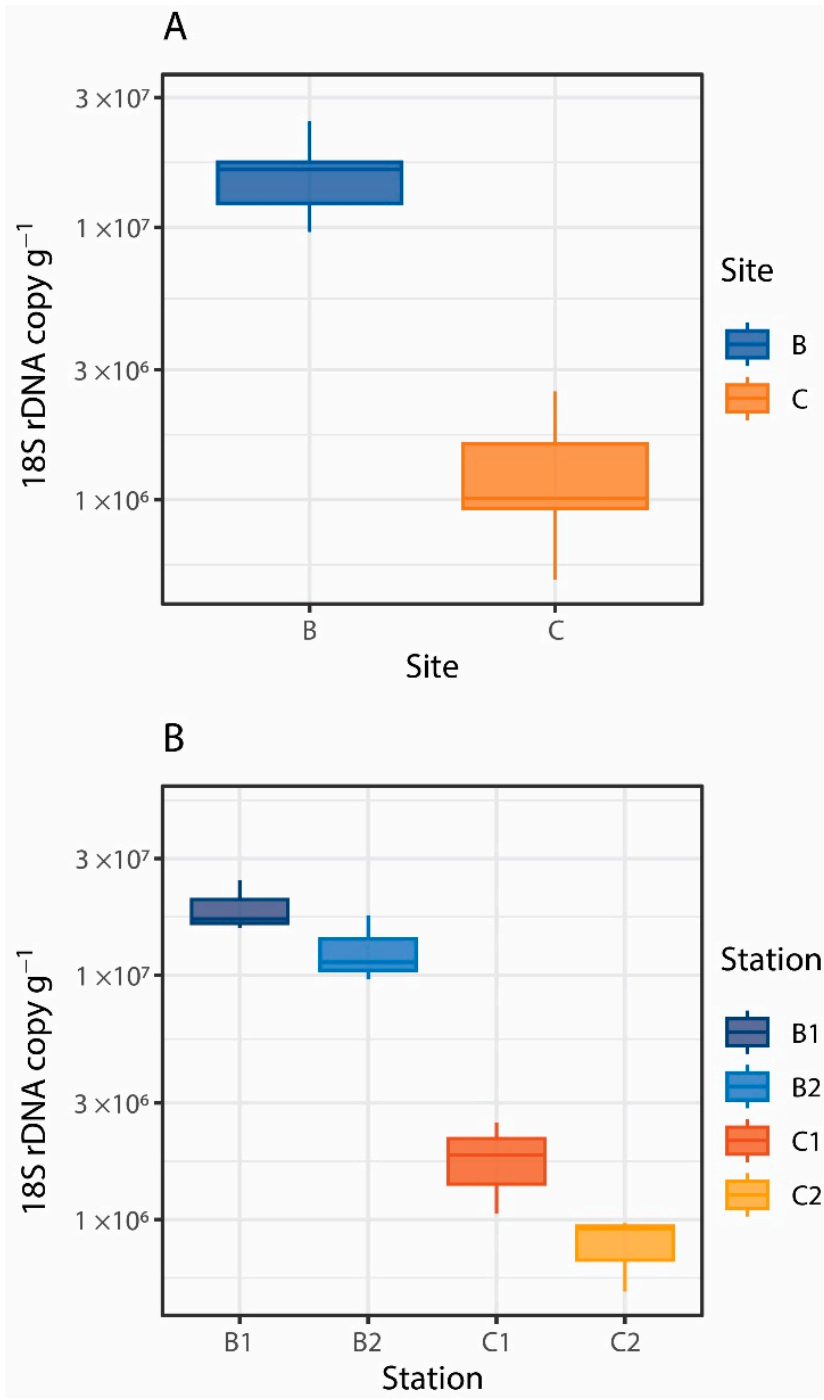

Figure 2. Boxplots showing fungal abundance, expressed as the number of $18 \mathrm{~S}$ rDNA copies per gram of dry sediment, of the two benthic deep-sea sites investigated (A) and of the stations within sites B and C (B).

The clustering of the 113,635 fungal ITS sequences obtained in the present study after trimming allowed us to identify a total of 1251 fungal ASVs. Rarefaction curves indicated that the sequencing effort was sufficient to describe the fungal diversity present in the benthic systems investigated, even after rarefaction to the lowest sequencing depth (Figure 4A). We found a high variability of fungal ASV richness between the two sites (Figure 4B), and also between the stations, in particular of Site C (Figure 4C). Fungal ASV richness was higher at Site $\mathrm{B}$, where a higher trophic availability was also found, compared to Site $\mathrm{C}\left(\mathrm{F}_{1,4}=108.2 ; p<0.01\right)$. However, the values of fungal richness reported 
in the present study fell within the range previously reported for other benthic deep-sea ecosystems [22,24], including Southern Ocean sediments [26].

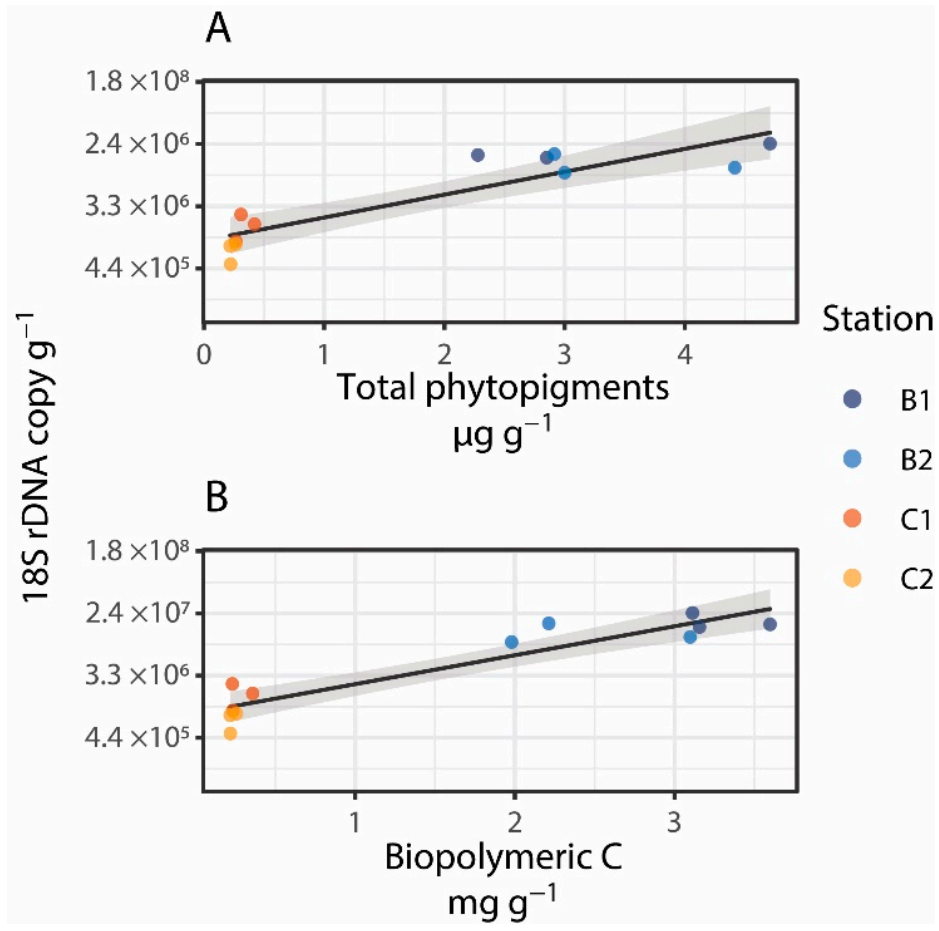

Figure 3. Relationships between fungal abundance (expressed as the number of $18 \mathrm{~S}$ rDNA copies per gram of dry sediment) and total phytopigment (A) and biopolymeric C (B) concentrations in the study area. Gray shade represents the $95 \%$ confidence interval of the linear model interpolating the observations.
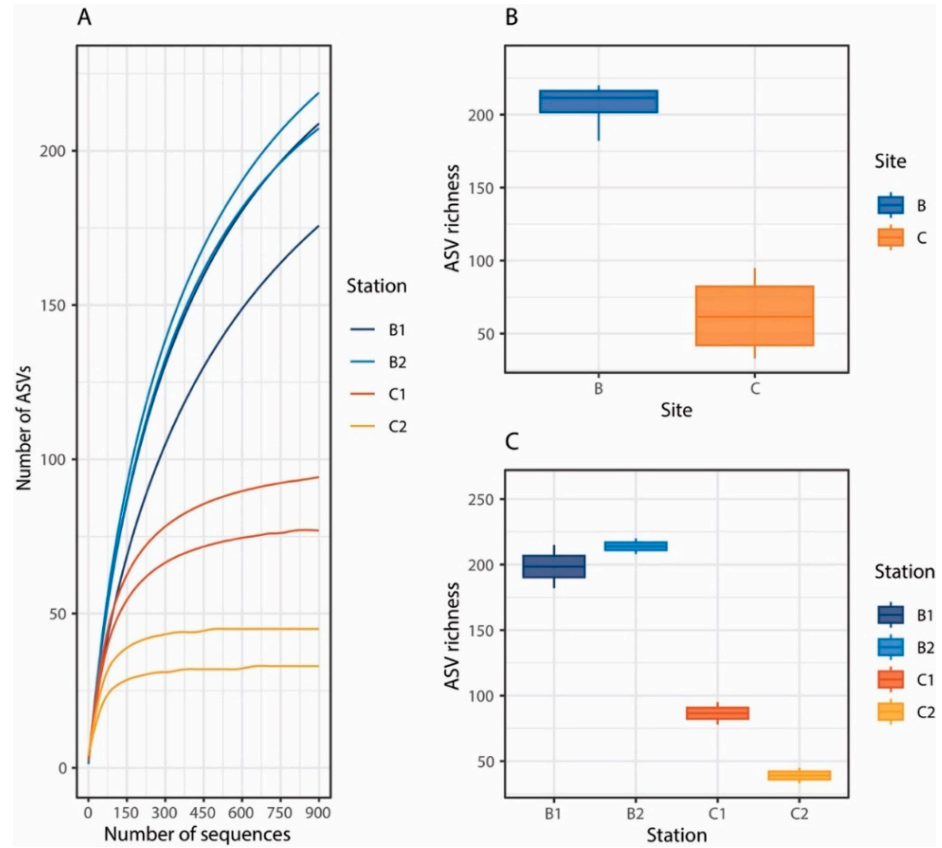

Figure 4. (A) Rarefaction curves from random subsampling (100 iterations) of 900 reads corresponding to the lowest read number obtained from the different sediment samples analyzed; (B) boxplot showing the fungal ASV richness in the two benthic deep-sea sites investigated, and (C) boxplot showing the fungal ASV richness in the four benthic deep-sea stations investigated. 
Taxonomic analysis showed that using a default confidence threshold (cutoff of 0.8), most of the fungal ASVs could not be assigned to known fungal taxa (on average ca. $90 \%$, Figures 5 and S1). Relaxing the confidence thresholds, the number of unknown fungal ASVs decreased ( $68 \%$ with a 0.6 cutoff and $58 \%$ with a 0.5 cutoff), but with a lessreliable classification (Figure S1). This result indicates that benthic deep-sea Antarctic sediments can harbor a large number of novel fungal lineages, while fungal ASVs affiliating to known fungal taxa included members affiliated to Ascomycota and Basidiomycota, which typically represent the main phyla reported in different benthic deep-sea ecosystems worldwide [24,26,27,32].

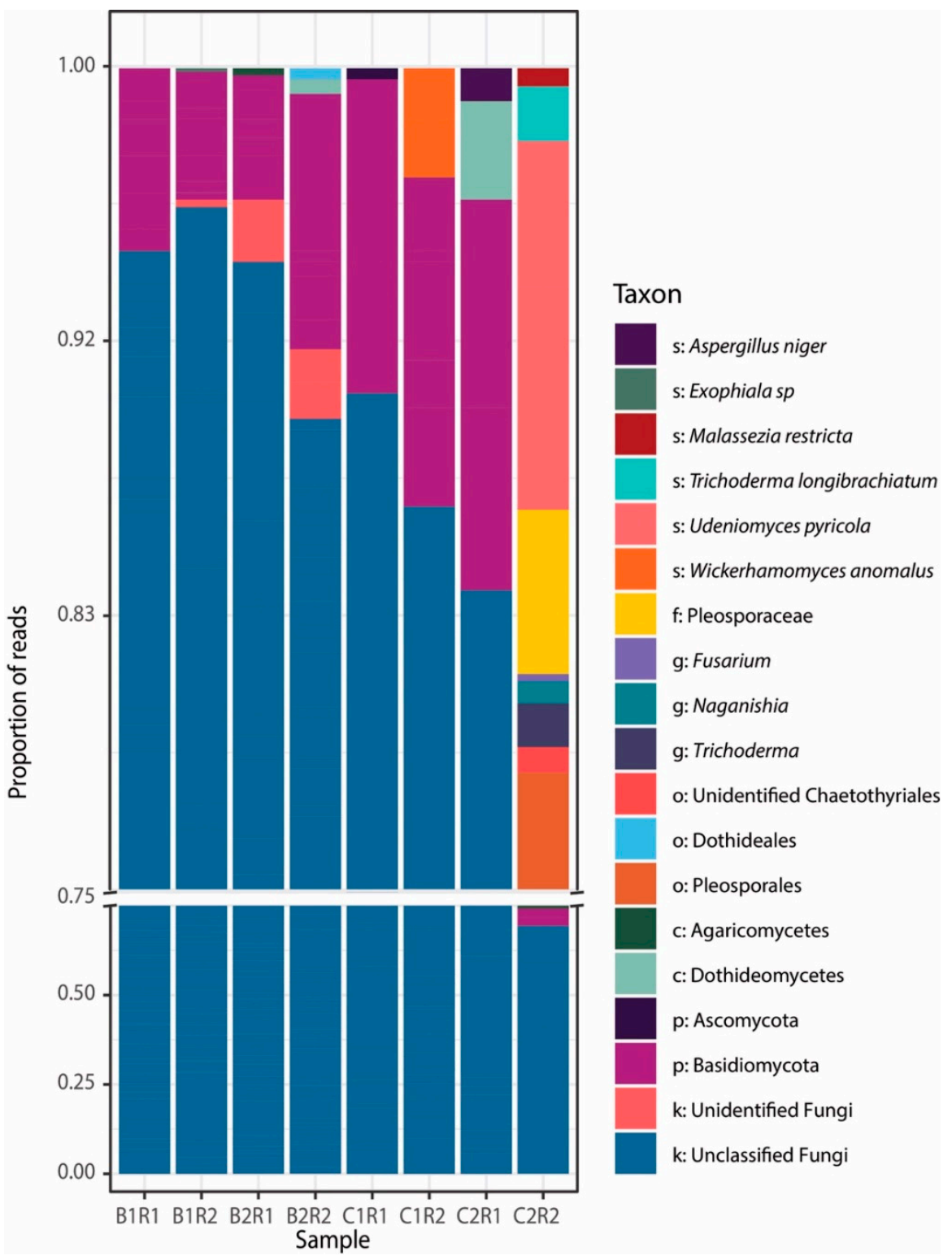

Figure 5. Stacked bar plot showing the relative abundance of fungal taxa at the lowest taxonomic levels identified in each deep-sea sediment sample collected in the Ross Sea. Taxonomic affiliation was assigned using a confidence threshold cutoff of 0.8 .

Only a few ASVs could be affiliated to known fungal genera. In particular, we found 12 ASVs affiliating to nine genera, including genera commonly encountered in a variety of benthic deep-sea ecosystems (e.g., Aspergillus; [24,32]) and polar systems (e.g., Naganishia, Dothideomycetes and Agaricomycetes; [27,74,75]). Fungi belonging to the genera Trichoderma found in this study were already reported and isolated from lake and 
sediments of the Penguin Island in Antarctica [76,77], while other genera commonly found in Antarctic sediments, such as Metschnikowia, Galciozyma and Psedogymnoascus, were not encountered (for a more detailed list see [28]). Furthermore, other fungal taxa, including members belonging to Fusarium and Wickerhamomyces, have been reported to be associated with Antarctic sponges and macroalgae [78-80], while taxa affiliated with Exophiala and Aspergillus have been previously isolated from different Antarctic marine samples [28,81]. Such a comparison suggests that Antarctic deep-sea sediments can host profoundly different fungal assemblages depending on specific environmental and ecological settings.

SIMPER analysis revealed a very low similarity between the fungal assemblage compositions of the two sites and within them, as highlighted by the network plot (Figure 6). In particular, the average similarity between stations of Site B were higher than those between stations of Site C (7.7 vs. 1.6\%), while the similarity between Site B and C was on average $<1 \%$. Such very low similarity values were due to the presence of a large fraction of exclusive ASVs of each sample (accounting for 76-94\% of the total ASVs; Figure 6). Overall, these findings suggest that differences in ecological and environmental conditions occurring even at spatial scales of a few meters (i.e., between replicates) can have a major role in shaping fungal assemblage composition, thus contributing to increase fungal turnover diversity.

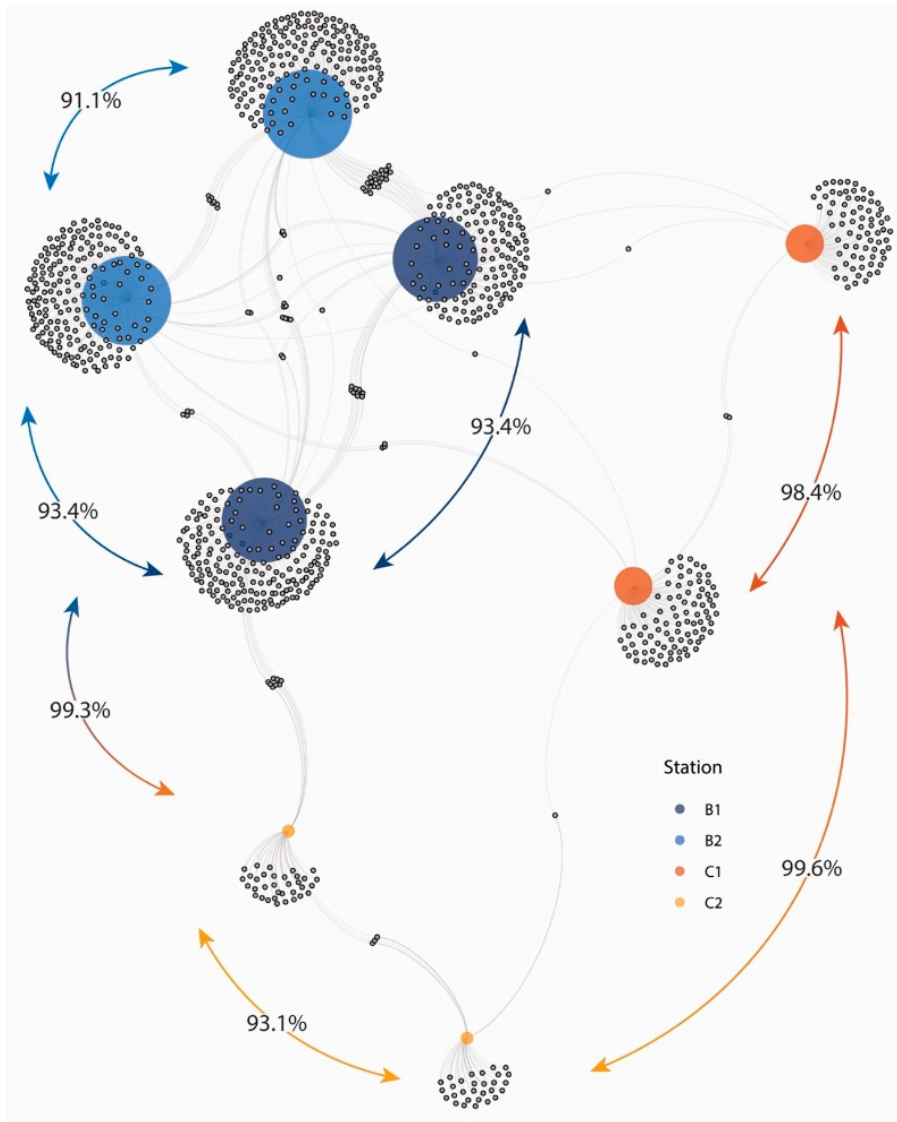

Figure 6. Network plot based on fungal assemblage composition found in the different sediment samples analyzed. Colored nodes represent sampling stations, while gray nodes represent the ASVs belonging to one or more samples to which are connected by gray edges. Arrows connecting samples indicate the Bray-Curtis dissimilarity calculated upon the log-transformed rarefied ASV table.

Previous studies suggested that environmental factors and trophic availability can influence fungal assemblage composition [24,82-84]. The distance-based redundancy analysis (dbRDA) allowed us to identify significant relationships between fungal assemblage composition and trophic (total phytopigment and biopolymeric $\mathrm{C}$ concentrations, protein to carbohydrate ratio) and environmental variables (temperature, salinity and oxygen 
concentrations). Altogether, the environmental and trophic variables explained $87 \%$ of the observed variation in fungal assemblage composition, but only temperature significantly explained $18 \%$ of the total variance (Figure 7 ). Thus, other factors acting at the local scale, such as habitat heterogeneity, competition and predation processes [85], may have an additional role in promoting a high diversification of benthic deep-sea fungi. Overall, results of the present study indicate that Antarctic deep-sea sediments host abundant and highly diversified fungal assemblages most of which still unidentified and suggest that fungi inhabiting Antarctic benthic deep-sea ecosystems can be sensitive to an interplay of environmental and ecological factors, whose variations, potentially induced also by climate changes, can profoundly influence their assemblage composition.

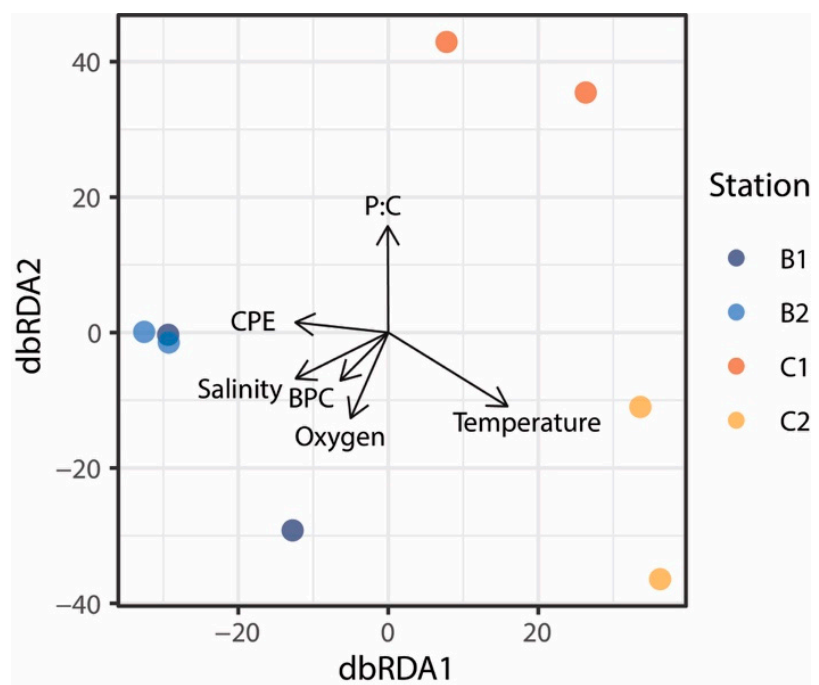

Figure 7. Output of the distance-based redundancy analysis (dbRDA) showing the relationships between the fungal assemblage composition and environmental and trophic variables analyzed in this study.

\section{Conclusions}

This study provides new insights into the quantitative relevance and diversity of benthic deep-sea fungi in the Ross Sea. Our findings reveal that the distribution of fungal abundance and richness is primarily driven by trophic availability, whereas an interplay of factors shapes fungal assemblage composition. Our findings also suggest that the spatial variability even at a small scale can promote important differences in deep-sea fungal assemblages, thus allowing for the maintenance of overall high fungal diversity. Results reported in this study could be relevant for a better understanding of the potential impact of thermohaline and trophic modifications due to climate changes on Antarctic deep-sea ecosystems. Modifications of ice coverage and thermohaline conditions affecting the planktonic food web structure could, indeed, profoundly influence organic carbon export to the seafloor, with cascading effects on benthic deep-sea biodiversity and ecosystem functioning. Although altered freezing and melting cycles of Antarctic pack ice are expected to drastically change ecosystem functioning, we still have a limited knowledge of biogeochemical cycles and ecological processes in which fungi are involved. Therefore, our results highlight the need to improve our understanding of the ecological role of benthic deep-sea fungi for better comprehension and prediction of the potential effects of climate changes on Antarctic deep-sea ecosystem functioning.

Supplementary Materials: The following supporting information can be downloaded at: https: / / www.mdpi.com/article/10.3390/jof8010065/s1: Figure S1. Taxonomic analysis of fungal ASVs obtained using 3 different confidence thresholds through the USEARCH SINTAX command.

Author Contributions: Conceptualization, A.D., C.C. and R.D.; methodology, G.B. and M.T.; data curation, G.B., M.T. and S.V.; writing-original draft preparation, G.B. and M.T.; writing-review 
and editing, A.D., C.C., S.V. and E.R.; funding acquisition, A.D. and R.D. All authors have read and agreed to the published version of the manuscript.

Funding: This research was carried out in the framework of the BEDROSE project financially supported by PNRA and the VIRIDE project (n. 2017EKFA98) financially supported by the Ministry of University and Research.

Institutional Review Board Statement: Not applicable.

Informed Consent Statement: Not applicable.

Data Availability Statement: Raw sequencing reads have been deposited in the NCBI Sequence Read Archive (SRA) under the accession numbers PRJNA791191.

Acknowledgments: The authors thank all the crew members for supporting sample collection.

Conflicts of Interest: The authors declare no conflict of interest.

\section{References}

1. Arrigo, K.R.; van Dijken, G.L.; Bushinsky, S. Primary production in the Southern Ocean, 1997-2006. J. Geophys. Res. Ocean 2008, 113, 1-27. [CrossRef]

2. Arrigo, K.R.; van Dijken, G.; Long, M. Coastal Southern Ocean: A strong anthropogenic $\mathrm{CO}_{2}$ sink. Geophys. Res. Lett. 2008, 35, $1-6$.

3. Arrigo, K.R.; van Dijken, G.L. Phytoplankton dynamics within 37 Antarctic coastal polynya systems. J. Geophys. Res. Ocean 2003, 108, 3271. [CrossRef]

4. Arrigo, K.R.; Van Dijken, G.L. Interannual variation in air-sea $\mathrm{CO}_{2}$ flux in the Ross Sea, Antarctica: A model analysis. J. Geophys. Res. Ocean 2007, 112, 1-16.

5. Smith, W.O.; Nelson, D.M. Importance of ice edge phytoplankton production in the Southern Ocean. Bioscience 1986, 36, $251-257$. [CrossRef]

6. Smith, W.O.; Gordon, L.I. Hyperproductivity of the Ross Sea (Antarctica) polynya during austral spring. Geophys. Res. Lett. 1997, 24, 233-236. [CrossRef]

7. Sweeney, $\mathrm{C}$. The annual cycle of surface water $\mathrm{CO}_{2}$ and $\mathrm{O}_{2}$ in the Ross Sea: A model for gas exchange on the continental shelves of Antarctica. Biogeochem. Ross Sea 2003, 78, 295-312.

8. Arrigo, K.R.; Van Dijken, G.L. Annual changes in sea-ice, chlorophyll $\alpha$, and primary production in the Ross Sea, Antarctica. Deep. Res. Part II Top. Stud. Oceanogr. 2004, 51, 117-138. [CrossRef]

9. Brandt, A.; De Broyer, C.; De Mesel, I.; Ellingsen, K.E.; Gooday, A.J.; Hilbig, B.; Linse, K.; Thomson, M.R.A.; Tyler, P.A. The biodiversity of the deep Southern Ocean benthos. Philos. Trans. R. Soc. B Biol. Sci. 2007, 362, 39-66. [CrossRef]

10. Griffiths, H.J. Antarctic Marine Biodiversity-What Do We Know About the Distribution of Life in the Southern Ocean? PLoS ONE 2010, 5, e11683. [CrossRef]

11. Danovaro, R.; Snelgrove, P.V.R.; Tyler, P. Challenging the paradigms of deep-sea ecology. Trends Ecol. Evol. 2014, 29 , 465-475. [CrossRef]

12. Bernhard, J.M.; Kormas, K.; Pachiadaki, M.G.; Rocke, E.; Beaudoin, D.J.; Morrison, C.; Visscher, P.T.; Cobban, A.; Starczak, V.R.; Edgcomb, V.P. Benthic protists and fungi of Mediterranean deep hypsersaline anoxic basin redoxcline sediments. Front. Microbiol. 2014, 5, 1-13. [CrossRef] [PubMed]

13. Edgcomb, V.P.; Pachiadaki, M.G.; Mara, P.; Kormas, K.A.; Leadbetter, E.R.; Bernhard, J.M. Gene expression profiling of microbial activities and interactions in sediments under haloclines of E. Mediterranean deep hypersaline anoxic basins. ISME J. 2016, 10, 2643-2657. [CrossRef]

14. Barone, G.; Varrella, S.; Tangherlini, M.; Rastelli, E.; Dell’Anno, A.; Danovaro, R.; Corinaldesi, C. Marine fungi: Biotechnological perspectives from deep-hypersaline anoxic basins. Diversity 2019, 11, 113. [CrossRef]

15. Nagahama, T.; Takahashi, E.; Nagano, Y.; Abdel-Wahab, M.A.; Miyazaki, M. Molecular evidence that deep-branching fungi are major fungal components in deep-sea methane cold-seep sediments. Environ. Microbiol. 2011, 13, 2359-2370. [CrossRef]

16. Thaler, A.D.; Van Dover, C.L.; Vilgalys, R. Ascomycete phylotypes recovered from a Gulf of Mexico methane seep are identical to an uncultured deep-sea fungal clade from the Pacific. Fungal Ecol. 2012, 5, 270-273. [CrossRef]

17. Burgaud, G.; Arzur, D.; Durand, L.; Cambon-Bonavita, M.A.; Barbier, G. Marine culturable yeasts in deep-sea hydrothermal vents: Species richness and association with fauna. FEMS Microbiol. Ecol. 2010, 73, 121-133. [CrossRef] [PubMed]

18. Burgaud, G.; Le Calvez, T.; Arzur, D.; Vandenkoornhuyse, P.; Barbier, G. Diversity of culturable marine filamentous fungi from deep-sea hydrothermal vents. Environ. Microbiol. 2009, 11, 1588-1600. [CrossRef] [PubMed]

19. Xu, W.; Guo, S.; Pang, K.L.; Luo, Z.H. Fungi associated with chimney and sulfide samples from a South Mid-Atlantic Ridge hydrothermal site: Distribution, diversity and abundance. Deep. Res. Part I Oceanogr. Res. Pap. 2017, 123, 48-55. [CrossRef]

20. Edgcomb, V.P.; Beaudoin, D.; Gast, R.; Biddle, J.F.; Teske, A. Marine subsurface eukaryotes: The fungal majority. Environ. Microbiol. 2011, 13, 172-183. [CrossRef] 
21. Orsi, W.; Biddle, J.F.; Edgcomb, V. Deep Sequencing of Subseafloor Eukaryotic rRNA Reveals Active Fungi across Marine Subsurface Provinces. PLOS ONE 2013, 8, e56335. [CrossRef]

22. Zhang, T.; Wang, N.F.; Zhang, Y.Q.; Liu, H.Y.; Yu, L.Y. Diversity and distribution of fungal communities in the marine sediments of Kongsfjorden, Svalbard (High Arctic). Sci. Rep. 2015, 5, 1-11. [CrossRef]

23. Pachiadaki, M.G.; Rédou, V.; Beaudoin, D.J.; Burgaud, G.; Edgcomb, V.P. Fungal and prokaryotic activities in the Marine subsurface biosphere at Peru Margin and canterbury basin inferred from RNA-based analyses and microscopy. Front. Microbiol. 2016, 7, 846. [CrossRef] [PubMed]

24. Barone, G.; Rastelli, E.; Corinaldesi, C.; Tangherlini, M.; Danovaro, R.; Dell'Anno, A. Benthic deep-sea fungi in submarine canyons of the Mediterranean Sea. Prog. Oceanogr. 2018, 168, 57-64. [CrossRef]

25. Ogaki, M.B.; Coelho, L.C.; Vieira, R.; Neto, A.A.; Zani, C.L.; Alves, T.M.A.; Junior, P.A.S.; Murta, S.M.F.; Barbosa, E.C.; Oliveira, J.G.; et al. Cultivable fungi present in deep-sea sediments of Antarctica: Taxonomy, diversity, and bioprospecting of bioactive compounds. Extremophiles 2020, 24, 227-238. [CrossRef]

26. Ogaki, M.B.; Pinto, O.H.B.; Vieira, R.; Neto, A.A.; Convey, P.; Carvalho-Silva, M.; Rosa, C.A.; Câmara, P.E.A.S.; Rosa, L.H. Fungi Present in Antarctic Deep-Sea Sediments assessed Using DNA Metabarcoding. Microb. Ecol. 2021, 82, 157-164. [CrossRef]

27. Rosa, L.H. Fungi of Antarctica Diversity, Ecology and Biotechnological Applications; Springer International Publishing: Cham, Germany, 2019; ISBN 978-3-030-18367-7.

28. Varrella, S.; Barone, G.; Tangherlini, M.; Rastelli, E.; Dell'anno, A.; Corinaldesi, C. Diversity, ecological role and biotechnological potential of antarctic marine fungi. J. Fungi 2021, 7, 391. [CrossRef] [PubMed]

29. Blackwell, M. The fungi: 1, 2, 3 ... 5.1 million species? Am. J. Bot. 2011, 98, 426-438. [CrossRef]

30. Hawksworth, D.L.; Rossman, A.Y. Where are all the undescribed fungi? Phytopathology 1997, 87, 888-891. [CrossRef] [PubMed]

31. Jeffries, T.C.; Curlevski, N.J.; Brown, M.V.; Harrison, D.P.; Doblin, M.A.; Petrou, K.; Ralph, P.J.; Seymour, J.R. Partitioning of fungal assemblages across different marine habitats. Environ. Microbiol. Rep. 2016, 8, 235-238. [CrossRef]

32. Vargas-Gastélum, L.; Riquelme, M. The mycobiota of the deep sea: What omics can offer. Life 2020, 10, 292. [CrossRef]

33. Tisthammer, K.H.; Cobian, G.M.; Amend, A.S. Global biogeography of marine fungi is shaped by the environment. Fungal Ecol. 2016, 19, 39-46. [CrossRef]

34. Li, W.; Wang, M.M.; Wang, X.G.; Cheng, X.L.; Guo, J.J.; Bian, X.M.; Cai, L. Fungal communities in sediments of subtropical Chinese seas as estimated by DNA metabarcoding. Sci. Rep. 2016, 6, 1-9. [CrossRef]

35. Orsi, W.D.; Vuillemin, A.; Coskun, Ö.K.; Rodriguez, P.; Oertel, Y.; Niggemann, J.; Mohrholz, V.; Gomez-Saez, G.V. Carbon assimilating fungi from surface ocean to subseafloor revealed by coupled phylogenetic and stable isotope analysis. ISME J. 2021, 15, 1-17. [CrossRef]

36. Hyde, K.D.; Jones, E.B.G.; Leaño, E.; Pointing, S.B.; Poonyth, A.D.; Vrijmoed, L.L.P. Role of fungi in marine ecosystems. Biodivers Conserv. 1998, 7, 1147-1161. [CrossRef]

37. Cathrine, S.J.; Raghukumar, C. Anaerobic denitrification in fungi from the coastal marine sediments off Goa, India. Mycol. Res. 2009, 113, 100-109. [CrossRef]

38. Jebaraj, C.S.; Raghukumar, C.; Behnke, A.; Stoeck, T. Fungal diversity in oxygen-depleted regions of the Arabian Sea revealed by targeted environmental sequencing combined with cultivation. FEMS Microbiol. Ecol. 2010, 71, 399-412. [CrossRef]

39. Dell'Anno, A.; Danovaro, R. Ecology: Extracellular DNA plays a key role in deep-sea ecosystem functioning. Science 2005, 309, 2179. [CrossRef]

40. Dell'Anno, A.; Pusceddu, A.; Corinaldesi, C.; Canals, M.; Heussner, S.; Thomsen, L.; Danovaro, R. Trophic state of benthic deep-sea ecosystems from two different continental margins off Iberia. Biogeosciences 2013, 10, 2945-2957. [CrossRef]

41. Grinhut, T.; Hadar, Y.; Chen, Y. Degradation and transformation of humic substances by saprotrophic fungi: Processes and mechanisms. Fungal Biol. Rev. 2007, 21, 179-189. [CrossRef]

42. Raghukumar, S. Animals in Coastal Benthic Ecosystem and Aquaculture Systems. In Fungi in Coastal and Oceanic Marine Ecosystems; Raghukumar, S., Ed.; Springer International Publishing: Cham, Germany, 2017; pp. 163-183. ISBN 978-3-319-54304-8.

43. Doney, S.C.; Ruckelshaus, M.; Emmett Duffy, J.; Barry, J.P.; Chan, F.; English, C.A.; Galindo, H.M.; Grebmeier, J.M.; Hollowed, A.B.; Knowlton, N.; et al. Climate change impacts on marine ecosystems. Ann. Rev. Mar. Sci. 2012, 4, 11-37. [CrossRef]

44. Garciá Molinos, J.; Halpern, B.S.; Schoeman, D.S.; Brown, C.J.; Kiessling, W.; Moore, P.J.; Pandolfi, J.M.; Poloczanska, E.S.; Richardson, A.J.; Burrows, M.T. Climate velocity and the future global redistribution of marine biodiversity. Nat. Clim. Chang. 2016, 6, 83-88. [CrossRef]

45. Silvano, A.; Foppert, A.; Rintoul, S.R.; Holland, P.R.; Tamura, T.; Kimura, N.; Castagno, P.; Falco, P.; Budillon, G.; Haumann, F.A.; et al. Recent recovery of Antarctic Bottom Water formation in the Ross Sea driven by climate anomalies. Nat. Geosci. 2020, 13, 780-786. [CrossRef]

46. Learman, D.R.; Henson, M.W.; Thrash, J.C.; Temperton, B.; Brannock, P.M.; Santos, S.R.; Mahon, A.R.; Halanych, K.M. Biogeochemical and microbial variation across $5500 \mathrm{~km}$ of Antarctic surface sediment implicates organic matter as a driver of benthic community structure. Front. Microbiol. 2016, 7, 284. [CrossRef]

47. Sweetman, A.K.; Thurber, A.R.; Smith, C.R.; Levin, L.A.; Mora, C.; Wei, C.L.; Gooday, A.J.; Jones, D.O.B.; Rex, M.; Yasuhara, M.; et al. Major impacts of climate change on deep-sea benthic ecosystems. Elementa 2017, 5, 4. [CrossRef]

48. Smith, W.O.; Ainley, D.G.; Arrigo, K.R.; Dinniman, M.S. The oceanography and ecology of the ross sea. Ann. Rev. Mar. Sci. 2014, 6, 469-487. [CrossRef] 
49. Fabiano, M.; Danovaro, R. Enzymatic activity, bacterial distribution, and organic matter composition in sediments of the Ross Sea (Antarctica). Appl. Environ. Microbiol. 1998, 64, 3838-3845. [CrossRef]

50. Dell'Anno, A.; Mei, M.L.; Pusceddu, A.; Danovaro, R. Assessing the trophic state and eutrophication of coastal marine systems: A new approach based on the biochemical composition of sediment organic matter. Mar. Pollut. Bull. 2002, 44, 611-622. [CrossRef]

51. Pusceddu, A.; Dell'Anno, A.; Fabiano, M.; Danovaro, R.; Dell'Anno, A.; Fabiano, M.; Danovaro, R. Quantity and bioavailability of sediment organic matter as signatures of benthic trophic status. Mar. Ecol. Prog. Ser. 2009, 375, 41-52. [CrossRef]

52. Danovaro, R. Methods for the Study of Deep-Sea Sediments, Their Functioning and Biodiversity; Danovaro, R., Ed.; CRC Press: Boca Raton, FL, USA, 2010; ISBN 9781439811382.

53. Taylor, J.D.; Cunliffe, M. Multi-year assessment of coastal planktonic fungi reveals environmental drivers of diversity and abundance. ISME J. 2016, 10, 2118-2128. [CrossRef] [PubMed]

54. Chemidlin Prévost-Bouré, N.; Christen, R.; Dequiedt, S.; Mougel, C.; Lelièvre, M.; Jolivet, C.; Shahbazkia, H.R.; Guillou, L.; Arrouays, D.; Ranjard, L. Validation and application of a PCR primer set to quantify fungal communities in the soil environment by real-time quantitative PCR. PLoS ONE 2011, 6, e24166. [CrossRef]

55. White, T.J.; Bruns, T.; Lee, S.; Taylor, J. Amplification and direct sequencing of fungal ribosomal RNA genes for phylogenetics. In PCR Protocols: A Guide to Methods and Applications; Innis, M.A., Gelfand, D.H., Sninsky, J.J., White, T.J., Eds.; Academic Press: New York, NY, USA, 1990; pp. 315-322.

56. Gardes, M.; Bruns, T.D. ITS primers with enhanced specificity for basidiomycetes-application to the identification of mycorrhizae and rusts. Mol. Ecol. 1993, 2, 113-118. [CrossRef]

57. Bolyen, E.; Rideout, J.R.; Dillon, M.R.; Bokulich, N.A.; Abnet, C.C.; Al-Ghalith, G.A.; Alexander, H.; Alm, E.J.; Arumugam, M.; Asnicar, F.; et al. Reproducible, interactive, scalable and extensible microbiome data science using QIIME 2. Nat. Biotechnol. 2019, 37, 852-857. [CrossRef] [PubMed]

58. Rivers, A.R.; Weber, K.C.; Gardner, T.G.; Liu, S.; Armstrong, S.D. ITSxpress: Software to rapidly trim internally transcribed spacer sequences with quality scores for marker gene analysis. F1000Research 2018, 7, 1418. [CrossRef] [PubMed]

59. Callahan, B.J.; McMurdie, P.J.; Rosen, M.J.; Han, A.W.; Johnson, A.J.A.; Holmes, S.P. DADA2: High-resolution sample inference from Illumina amplicon data. Nat. Methods 2016, 13, 581-583. [CrossRef] [PubMed]

60. Edgar, R.C. Accuracy of taxonomy prediction for 16S rRNA and fungal ITS sequences. PeerJ 2018, 2018, e4652. [CrossRef]

61. Hughes, J.B.; Hellmann, J.J. The application of rarefaction techniques to molecular inventories of microbial diversity. Methods Enzymol. 2005, 397, 292-308. [PubMed]

62. Gihring, T.M.; Green, S.J.; Schadt, C.W. Massively parallel rRNA gene sequencing exacerbates the potential for biased community diversity comparisons due to variable library sizes. Environ. Microbiol. 2012, 14, 285-290. [CrossRef] [PubMed]

63. Anderson, M.J. A new method for non-parametric multivariate analysis of variance. Austral Ecol. 2001, $26,32-46$.

64. Anderson, M.J. Permutation tests for univariate or multivariate analysis of variance and regression. Can. J. Fish. Aquat. Sci. 2001, 58, 626-639. [CrossRef]

65. Bastian, M.; Heymann, S.; Jacomy, M. Gephi: An open source software for exploring and manipulating networks. In Proceedings of the Third International AAAI Conference on Weblogs and Social Media, San Jose, CA, USA, 17-20 May 2009.

66. Clarke, K.R. Non-parametric multivariate analyses of changes in community structure. Aust. J. Ecol. 1993, 18, 117-143. [CrossRef]

67. McArdle, B.H.; Anderson, M.J. Fitting Multivariate Models to Community Data: A Comment on Distance-Based Redundancy Analysis. Ecology 2001, 82, 290. [CrossRef]

68. Bergamasco, A.; Defendi, V.; Zambianchi, E.; Spezie, G. Evidence of dense water overflow on the Ross Sea shelf-break. Antarct. Sci. 2002, 14, 271-277. [CrossRef]

69. Gardner, W.D.; Richardson, M.J.; Smith, W.O. Seasonal patterns of water column particulate organic carbon and fluxes in the ross sea, antarctica. Deep. Res. Part II Top. Stud. Oceanogr. 2000, 47, 3423-3449. [CrossRef]

70. Frignani, M.; Giglio, F.; Accornero, A.; Langone, L.; Ravaioli, M. Sediment characteristics at selected sites of the Ross Sea continental shelf: Does the sedimentary record reflect water column fluxes? Antarct. Sci. 2003, 15, 133-139. [CrossRef]

71. Danovaro, R.; Molari, M.; Corinaldesi, C.; Dell'Anno, A. Macroecological drivers of archaea and bacteria in benthic deep-sea ecosystems. Sci. Adv. 2016, 2, 1-12. [CrossRef] [PubMed]

72. Wei, C.L.; Rowe, G.T.; Briones, E.E.; Boetius, A.; Soltwedel, T.; Caley, M.J.; Soliman, Y.; Huettmann, F.; Qu, F.; Yu, Z.; et al. Global patterns and predictions of seafloor biomass using random forests. PLOS ONE 2010, 5, e15323. [CrossRef]

73. Xu, W.; Pang, K.L.; Luo, Z.H. High Fungal Diversity and Abundance Recovered in the Deep-Sea Sediments of the Pacific Ocean. Microb. Ecol. 2014, 68, 688-698. [CrossRef]

74. Rämä, T.; Hassett, B.T.; Bubnova, E. Arctic marine fungi: From filaments and flagella to operational taxonomic units and beyond. Bot. Mar. 2017, 60, 433-452. [CrossRef]

75. Duarte, A.W.F.; dos Santos, J.A.; Vianna, M.V.; Vieira, J.M.F.; Mallagutti, V.H.; Inforsato, F.J.; Wentzel, L.C.P.; Lario, L.D.; Rodrigues, A.; Pagnocca, F.C.; et al. Cold-adapted enzymes produced by fungi from terrestrial and marine Antarctic environments. Crit. Rev. Biotechnol. 2018, 38, 600-619. [CrossRef]

76. Ren, J.; Xue, C.; Tian, L.; Xu, M.; Chen, J.; Deng, Z.; Proksch, P.; Lin, W. Asperelines A-F, Peptaibols from the Marine-Derived Fungus Trichoderma asperellum. J. Nat. Prod. 2009, 72, 1036-1044. [CrossRef]

77. Gonçalves, V.N.; Vaz, A.B.M.; Rosa, C.A.; Rosa, L.H. Diversity and distribution of fungal communities in lakes of Antarctica. FEMS Microbiol. Ecol. 2012, 82, 459-471. [CrossRef] 
78. Godinho, V.M.; Furbino, L.E.; Santiago, I.F.; Pellizzari, F.M.; Yokoya, N.S.; Pupo, D.; Alves, T.M.A.; S Junior, P.A.; Romanha, A.J.; Zani, C.L.; et al. Diversity and bioprospecting of fungal communities associated with endemic and cold-adapted macroalgae in Antarctica. ISME J. 2013, 7, 1434-1451. [CrossRef] [PubMed]

79. Furbino, L.E.; Godinho, V.M.; Santiago, I.F.; Pellizari, F.M.; Alves, T.M.A.A.; Zani, C.L.; Junior, P.A.S.S.; Romanha, A.J.; Carvalho, A.G.O.O.; Gil, L.H.V.G.V.G.; et al. Diversity Patterns, Ecology and Biological Activities of Fungal Communities Associated with the Endemic Macroalgae Across the Antarctic Peninsula. Microb. Ecol. 2014, 67, 775-787. [CrossRef]

80. Wang, F.; Sheng, J.; Chen, Y.; Xu, J. Microbial diversity and dominant bacteria causing spoilage during storage and processing of the Antarctic krill, Euphausia superba. Polar Biol. 2021, 44, 163-171. [CrossRef]

81. Gonçalves, V.N.; Vitoreli, G.A.; de Menezes, G.C.A.; Mendes, C.R.B.; Secchi, E.R.; Rosa, C.A.; Rosa, L.H. Taxonomy, phylogeny and ecology of cultivable fungi present in seawater gradients across the Northern Antarctica Peninsula. Extremophiles 2017, 21, 1005-1015. [CrossRef] [PubMed]

82. Richards, T.A.; Talbot, N.J. Horizontal gene transfer in osmotrophs: Playing with public goods. Nat. Rev. Microbiol. 2013, 11, 720-727. [CrossRef] [PubMed]

83. Richards, T.A.; Leonard, G.; Mahé, F.; Del Campo, J.; Romac, S.; Jones, M.D.M.; Maguire, F.; Dunthorn, M.; De Vargas, C.; Massana, R.; et al. Molecular diversity and distribution of marine fungi across 130 european environmental samples. Proc. R. Soc. B Biol. Sci. 2015, 282, 20152243. [CrossRef] [PubMed]

84. Couturier, M.; Bennati-Granier, C.; Urio, M.B.; Ramos, L.P.; Berrin, J.G. Fungal enzymatic degradation of cellulose. In Green Fuels Technology; Green Energy and Technology; Soccol, C., Brar, S., Faulds, C., Ramos, L., Eds.; Springer: Cham, Switzerland, 2016; pp. 133-146.

85. Fabiano, M.; Danovaro, R. Meiofauna distribution and mesoscale variability in two sites of the Ross Sea (Antarctica) with contrasting food supply. Polar Biol. 1999, 22, 115-123. [CrossRef] 